\title{
Cytogenetic, immunological, and haematological effects in workers in an ethylene oxide manufacturing plant
}

\author{
N J VAN SITTERT, ' G DE JONG,${ }^{2}$ M G CLARE, ${ }^{3}$ R DAVIES,${ }^{3}$ B J DEAN,${ }^{3}$ L J WREN, ${ }^{3}$ AND \\ A S WRIGHT ${ }^{3}$ \\ From the Health and Safety and Environment Division, ${ }^{1}$ Shell Internationale Petroleum Maatschappij, The \\ Hague, and the Medical Department (BGD), ${ }^{2}$ Shell Nederland Raffinaderij/Shell Nederland Chemie, \\ Rotterdam, The Netherlands, and Shell Toxicology Laboratory (Tunstall), ${ }^{3}$ Sittingbourne Research Centre, \\ Sittingbourne, United Kingdom
}

ABSTRACT Samples of blood were collected from a group of plant workers engaged in the manufacture of ethylene oxide (EO) for periods of up to 14 years and also from a group of control personnel matched by age and smoking habits. Peripheral blood lymphocytes were cultured for cytogenetic analysis. Selected immune and haematological parameters were also investigated. The results of these studies showed no statistically significant difference between the group of plant workers and the control group in respect of any of the biological parameters investigated in this study. Nevertheless, duration of employment in EO manufacturing was positively correlated $(p<0.05)$ with the frequency of chromosome breaks and with the percentage of neutrophils in a differential white blood cell count and negatively correlated ( $p<$ 0.05 ) with the percentage of lymphocytes. As the values of these parameters remained within the normal limits of control populations, the correlations were considered to have no significance for health. Atmospheric concentrations of EO were determined using personnel air samplers and were generally below the detection limit $(<0.05 \mathrm{ppm})$ during stable plant operations, although transient concentrations of up to $8 \mathrm{ppm}$ were occasionally recorded. The amount of alkylation (2-hydroxyethyl groups) of the $\mathrm{N}^{t}$ atom of histidinyl residues in haemoglobin was also measured in an attempt to gauge recent individual exposures to EO. Variable but, in most instances, readily measurable amounts of $\mathrm{N}^{t}$-(2'-hydroxyethyl)-L-histidine ( $\mathrm{N}^{t}$ represents the $\mathrm{N}_{3}$ atom of histidine) were found in the haemoglobin of plant workers and in the control group who had not knowingly been exposed to an exogenous source of EO. There was no statistically significant difference between the results obtained in the control group and in the group of plant workers.

Ethylene oxide (EO) has been shown to induce mutations in bacteria, plants, and animals. ${ }^{1-4}$ The results of a recent series of publications provide clear evidence of a causal association between prolonged exposure to EO in excess of $1 \mathrm{ppm}(8 \mathrm{~h}$ TWA) and an increased occurrence of chromosome aberrations in the lymphocytes of human peripheral blood. $^{5-7}$ The exposure data lack precision, however, and are therefore not entirely satisfactory for application in quantitative risk assessment. It was thus considered important to determine

Received 24 August 1983

Accepted 9 December 1983 whether or not employment in a modern EO manufacturing plant was associated with an increased frequency of chromosome aberrations. Furthermore, because an increase in the incidence of chromosome aberrations is regarded as direct evidence of genotoxic action in vivo, it was considered pertinent to include an evaluation of certain parameters that might prove to be sensitive health indicators of exposure to genotoxic agents. For example, genotoxic agents, such as alkylating agents can depress immunological responsiveness in patients treated with cytostatic drugs. ${ }^{8}$ Accordingly, we included an assessment of the status of the cells of the immune system and related haematological parameters. 
The measurement of exposure to $\mathrm{EO}$ was an essential component of this study. The accurate determination of exposure is a problem common to most industrial epidemiological studies. In an attempt to overcome this problem two independent methods, one direct the other indirect, were used to determine exposures to EO. In the first method atmospheric concentrations of $\mathrm{EO}$ were measured using personal air samplers whereas in the second a procedure developed by Ehrenberg and his colleagues $^{9-13}$ was used to develop precise data regarding recent individual exposures to EO. This method is based on measurements of the amount of a stable product, $\mathrm{N}^{\mathrm{t}}$-(2'-hydroxyethyl)-L-histidine, ${ }^{*}$ formed by reaction of $\mathrm{EO}$ with histidine residues in the haemoglobin of circulating erythrocytes. The method was applied to the plant workers and to a control group of personnel employed in administrative duties unconnected with EO manufacturing operations and remote from any possible exposure to EO.

\section{Methods}

\section{STUDY P.OPULATION}

Table 1 shows the characteristics of a group of EO plant workers and the control group. The plant workers were 36 men aged 20-59 (average age 32) who at the time of the examination (1980) had been engaged in EO manufacturing for periods of between one to 14 years. In the control group were 35 men matched by age and smoking habits, who had no operational involvement in the manufacturing process and who were believed to have had no previous occupational exposure to EO or other chemicals. The plant workers were divided into two groups: in group 1 were 19 men with less

Table 1 Characteristics of study groups

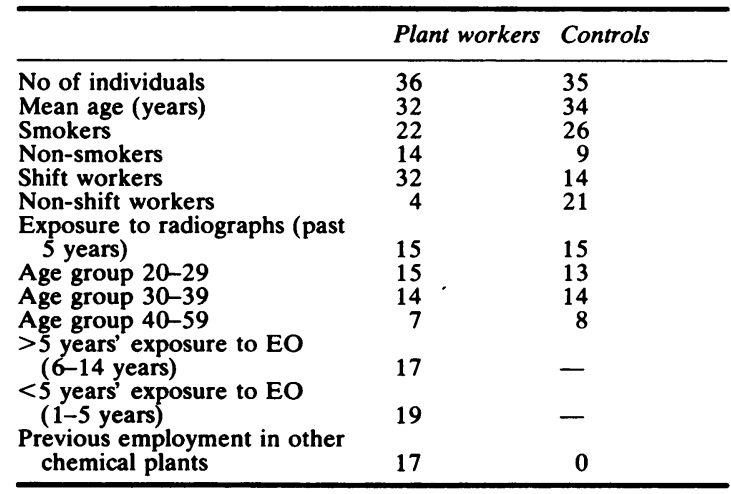

*According to IUPAC nomenclature the $\mathrm{N}^{t}$ atom represents the $\mathrm{N}_{3}$ atom of histidine. than five years' employment in the EO plant and in group 217 men with more than five years' employment. In addition to EO exposure the influence of other variables such as smoking, age, shift work, recent exposure to radiography, and previous employment in other chemical plants was also examined.

The plant workers have been employed in a modern, open air, EO manufacturing plant. Apart from EO, various other chemicals are used in the plant. None of these chemicals was believed to be associated with the biological effects investigated in this study. All individuals participated in the cytogenetic study but because of technical difficulties not all the plant workers and control subjects were examined by immunological and haematological analysis.

The study took place over a period of four weeks in January and February 1980.

\section{EO EXPOSURE MONITORING}

EO air monitoring surveys using personal samplers were carried out on occasions in 1974, 1978, 1980, and 1981, using the sampling method and the analytical technique recommended by NIOSH. ${ }^{14}$ The limit of detection of EO in air with this method was $0.05 \mathrm{ppm}$ for an eight hour sampling period. Exposure to EO was not measured during 1966-73.

BLOOD SAMPLING PROCEDURE AND DESPATCH OF SAMPLES

Approximately $20 \mathrm{ml}$ of blood was collected by venepuncture in heparinised polystyrene tubes $(25$ IU preservative free heparin per $\mathrm{ml}$ blood). Syringes and tubes used in this study were not sterilised with EO.

Equal numbers of blood samples from the plant workers and control groups were despatched by air and road to the Shell Toxicology Laboratory (Tunstall), Sittingbourne, United Kingdom, for chromosome analysis, assessment of immunological parameters, and determination of the degree of alkylation of histidine residues in haemoglobin. Samples reached their destination within 24 hours of venepuncture. Haematological analyses were carried out in the medical department of the manufacturing site using standard haematological methods.

\section{CHROMOSOME ANALYSIS}

Cultures were begun on receipt of the samples, generally about 24 hours after the blood had been collected. The detailed method for the culture, harvesting, and staining of lymphocytes has been described by Evans and $O^{\prime}$ Riordan. ${ }^{15}$ An aliquot sample of $0.8 \mathrm{ml}$ blood was incubated at $37^{\circ} \mathrm{C}$ for either $48 \mathrm{~h}$ or $72 \mathrm{~h}$ in $10 \mathrm{ml}$ Hams F10 culture 
Cytogenetic, immunological, and hematological effects in workers in an ethylene oxide manufacturing plant

medium, supplemented with fetal calf serum, $\mathrm{NaHCO}_{3}$ solution, benzyl penicillin, streptomycin sulphate, and phytohaemagglutinin. Three hours before the end of the incubation period, colcemid was added to a final concentration of $0.2 \mu \mathrm{g} / \mathrm{ml}$. After centrifugation, cells were incubated in $10 \mathrm{ml}$ $0.075 \mathrm{M} \mathrm{KCl}$ at $37^{\circ} \mathrm{C}$ for eight minutes and after another centrifugation the cells were fixed in a $3: 1$ mixture of methanol and acetic acid. For each culture two slides were prepared and then randomised and coded. One hundred metaphases were analysed from cultures incubated for $\mathbf{4 8}$ hours. If insufficient metaphases were present after 48 hours cultures incubated for 72 hours were examined. The cells were analysed for gaps, chromatid and chromosome aberrations, and for polyploidy, provided that they contained at least 44 chromosomes. Chromatid aberrations included breaks, single fragments, and exchanges, and chromosome aberrations included breaks, rings, dicentrics, and translocations.

\section{IMMUNOLOGICAL ANALYSIS}

$T$ cells were identified using the $E$ rosette technique and $B$ cells by direct immunofluorescence after tagging of phagocytic cells with latex particles. T lymphocyte function was assessed by a trảnsformation test in which radiolabelled thymidine incorporation was measured in control cultures and in cultures stimulated by a range of concentrations of the $\mathrm{T}$ cell mitogen, phytohaemagglutinin (PHA) The serum concentrations of immunoglobulins $G$, $\mathbf{M}$, and $\mathbf{A}$ were determined by the Laurell rocket immunoelectrophoretic technique, giving an indirect estimate of B cell function. Haematological analysis included white blood cell counts and differential white blood cell counts.

\section{DETERMINATION OF THE AMOUNT OF}

\section{$\mathrm{N}^{\mathrm{t}}$-(2'-HYDROXYETHYL)-L-HISTIDINE IN}

HAEMOGLOBIN

Red blood cells were sedimented at $400 \mathrm{~g}$ for 10 minutes, washed by gently suspending in isotonic saline $(10 \mathrm{ml})$, and recentrifuged at $400 \mathrm{~g}$. The washed red cells were frozen and stored at $-40^{\circ} \mathrm{C}$ before analysis. The isolation of haemoglobin from red blood cells and the hydrolysis of protein was performed using a modification of the method of Calleman et al. ${ }^{11}$ Globin (100 mg) was dissolved in $6 \mathrm{M} \mathrm{HCl}(10 \mathrm{ml})$. An aliquot of 15 000-20 $000 \mathrm{dpm}$ of $\mathrm{N}^{\mathrm{t}}$-( $\left(2^{\prime}\right.$-hydroxyethyl)-L-(ring-2- $\left.{ }^{14} \mathrm{C}\right)$ histidine (synthesised in Sittingbourne Research Centre; specific activity $55 \mathrm{mCi} / \mathrm{mmol}$ ) was added to each sample before hydrolysis to calculate losses during the experiment. Mercaptoethanol $(0 \cdot 1 \mathrm{ml})$ and 1 -octanol $(0.1 \mathrm{ml})$ were added, and hydrolysis was conducted at $120^{\circ} \mathrm{C}$ for 16 hours in vacuo. $\mathrm{N}^{\mathrm{t}}$-(2'-hydroxyethyl)-L-histidine was isolated from the hydrolysate by preparative HPLC on Partisil 10 SCX. This was done by washing the column first with $0.025 \mathrm{M} \mathrm{NH}_{4} \mathrm{H}_{2} \mathrm{PO}_{4}$ buffer, $\mathrm{pH} 4.6$ for 10 minutes at a flow rate of $8 \mathrm{ml} / \mathrm{min}$, at which conditions the neutral and acidic amino acids were eluted. Then the column was washed with $0.075 \mathrm{M}$ $\mathrm{NH}_{4} \mathrm{H}_{2} \mathrm{PO}_{4}$ buffer, $\mathrm{pH} \mathrm{4.6}$ at the same flow rate, at which conditions the basic amino acids were eluted. The retention time of $\mathrm{N}^{\mathrm{t}}$-(2'-hydroxyethyl) L-histidine was 18 minutes. The solution containing the adduct was desalted on Dowex $50 \mathrm{~W}-\mathrm{X} 8$ by elution with $400 \mathrm{ml} 0.5 \mathrm{M} \mathrm{HCl}$ and the adduct was eluted with $2 \times 100 \mathrm{ml} 4 \mathrm{M} \mathrm{HCl}$. After evaporation of the solution at low temperature the adduct was derivatised after addition of $75 \mathrm{ng}$ of deuterated $\mathrm{N}^{t}$-(2'-hydroxyethyl)-L-histidine to serve as internal standard, by reaction with methanolic $\mathrm{HCl}$ and heptafluorobutyric anhydride. Quantitation was carried out by gas chromatography on Ultrabond II coupled with chemical ionisation mass spectrometry. Isobutane was employed as the ionising gas, and the $\mathrm{M}+1$ ions of both $\mathrm{N}^{\mathrm{t}}$-(2'-hydroxyethyl)-L-histidine and deuterated internal standard were monitored using the mass spectrometer in the multiple ion detection mode. The amount of alkylation was calculated as nanomoles $\mathrm{N}^{\mathrm{t}}$-(2'-hydroxyethyl)-L-histidine per gram of globin. The average recovery value was $70 \%$. The limit of detection was $0.02 \mathrm{nmol} / \mathrm{g}$ of globin.

\section{STATISTICAL ANALYSIS}

The percentage of cells showing chromosome damage were calculated with their standard errors assuming a Poisson distribution of aberrations. This analysis was also done on the different types of cells in a differential white blood cell count. Normality of distribution of immunological and haematological parameters and of haemoglobin alkylation was tested by drawing normal probability plots. Parameters that were not normally distributed were logarithmically transformed. Differences between two variables at the $5 \%$ significance level were calculated using Student's $t$ test. The relation between variables was investigated using linear regression analysis.

\section{Results}

\section{EXPOSURE MEASUREMENTS}

\section{EO air concentrations}

Table 2 shows EO exposures of plant workers during 1974-81; most were below the limit of detection ( $0.05 \mathrm{ppm})$. In surveys carried out in 1974 
and 1980, however, about $10 \%$ of the measurements yielded EO exposures higher than $0.1 \mathrm{ppm}$, with a maximum of $8 \mathrm{ppm}$ in 1980 . During $1981,50 \%$ of the measurements exceeded $0 \cdot 1 \mathrm{ppm}$. The geometric mean EO exposure, calculated by linear extrapolation, was below $0.01 \mathrm{ppm}$ in surveys carried out in 1974, 1978, and 1980. The corresponding value in 1981 was $0.12 \mathrm{ppm}$.

\section{Haemoglobin alkylation}

Table 3 shows the mean values and the ranges of the amounts of $\mathrm{N}^{\mathrm{t}}$-(2'-hydroxyethyl)-L-histidine in the haemoglobin of plant workers and control subjects. The mean value was slightly higher in the plant workers than in the control group but the increase was not statistically significant. The equivalent tissue (in vivo) doses* of EO were calculated from histidine alkylation levels using the criteria developed by Ehrenberg and co-workers ${ }^{10} 11$ and are also shown in table 3 .

\section{CHROMOSOME ANALYSIS}

Table 4 shows the percentages of aberrant cells in the plant workers and in the control group. There was no statistically significant difference between the frequency of any of the types of aberrations noted in the lymphocytes of the plant workers' group compared with the controls.

${ }^{*}$ The in vivo dose is a function of concentration and exposure time and is expressed in terms of a composite unit, concentration $\times$ time-for instance, $\mu M \times h$. The calculation of the in vivo dose assumes a repeated and regular pattern of exposure to EO during the 18 week period immediately before blood sampling.
Table 2 Exposure of plant workers to ethylene oxide 1974-81. (Number of samples taken are given in parentheses)

\begin{tabular}{|c|c|c|c|}
\hline $\begin{array}{l}\text { Year of } \\
\text { monitoring }\end{array}$ & $\begin{array}{l}\text { Sampling } \\
\text { period }(h)\end{array}$ & $\begin{array}{l}\text { EO air concentration } \\
(p p m)\end{array}$ & $\begin{array}{l}\text { Geometric } \\
\text { mean* EO air } \\
\text { concentration } \\
(\text { ppm })\end{array}$ \\
\hline $\begin{array}{l}1974 \\
1978 \\
1980 \\
1981\end{array}$ & $\begin{array}{l}0 \cdot 5 \\
8 \\
8 \\
8\end{array}$ & $\begin{array}{l}<0.1(152) ; 0.1-4.9(18) \\
<0.05(26) ; 0.05-0.1(20) \\
<0.05(40) ; 0.1-8.0(5) \\
<0.05(6) ; 0.1-1.3(6)\end{array}$ & $\begin{array}{r}<0.01 \\
<0.01 \\
<0.01 \\
0.12\end{array}$ \\
\hline
\end{tabular}

*Calculated by linear extrapolation on log probability paper.

Table 5 summarises the data of individuals in the respective groups 1 and 2 . There was no statistically significant difference in the frequency of aberrant cells in group 1 compared with group 2 or between these groups and the control group.

Certain other factors such as smoking, shift work, previous employment in other chemical plants, and recent exposure to radiography were found to have no statistically significant effect on the frequency of chromatid or chomosome aberrations in either the plant workers or the control group. Regression analysis showed that the frequency of chromosome breaks in cultures from plant workers was positively correlated $(p<0.05)$ with the duration of employment. This trend was not solely attributable to the age of the men, since there was no significan correlation $(p>0.05)$ between age and number o aberrations.

No significant correlations $(p>0.05)$ were found between either the frequency of gaps or the frequency of chromatid aberrations and duration of employment or age. Regression analysis showed no

Table 3 Degree of alkylation of histidine in haemoglobin and corresponding weekly in vivo EO doses in plant workers and the control group

\begin{tabular}{|c|c|c|c|c|c|}
\hline Group & \multicolumn{3}{|c|}{$N^{\mathrm{t}}-\left(2^{\prime}-\right.$ hydroxyethyl)-L-histidine (nmol/g globin) } & \multicolumn{2}{|c|}{ In vivo dose; $\left(\mu M \times h \times\right.$ week $\left.^{-1}\right)$} \\
\hline \multicolumn{2}{|c|}{ No of individuals } & Mean $\pm S E M$ & Range & $M e a n \pm S E M$ & Range \\
\hline $\begin{array}{l}\text { Plant workers } \\
\text { Controls }\end{array}$ & $\begin{array}{l}32 \\
31\end{array}$ & $\begin{array}{l}2.08 \pm 0.24 \\
1.59 \pm 0.18\end{array}$ & $\begin{array}{l}<0.02-9.7^{*} \\
<0.02-4.7\end{array}$ & $\begin{array}{l}<16.5 \pm 1.9 \\
<12.6 \pm 1.4\end{array}$ & $\begin{array}{l}<0.16-76.9 \\
<0.16-37.3\end{array}$ \\
\hline
\end{tabular}

*This high value is based on a poor chromatogram and is therefore considered unreliable. Nevertheless, the result has not been excluded from the statistical analyses. If this result is excluded the range would be $<0 \cdot 02-6 \cdot 5$.

Table 4 Chromosome analysis of plant workers and controls. Data show the percentage of aberrant cells $\pm 1 S E M$

\begin{tabular}{lccc}
\hline & Plant workers & Controls & Statistical analysis \\
\hline No of metaphases analysed & 3600 & 3444 & NS \\
Polyploidy & $0.06 \pm 0.04$ & $0.20 \pm 0.08$ & NS \\
Gaps & $0.89 \pm 0.16$ & $0.80 \pm 0.15$ & NS \\
Chromatid aberrations & $0.50 \pm 0.11$ & $0.31 \pm 0.09$ & NS \\
Chromatid breaks & $0.03 \pm 0.03$ & 0.00 & NS \\
Chromatid exchanges & $0.22 \pm 0.08$ & $0.26 \pm 0.08$ & NS \\
Chromosome aberrations & 0.00 & 0.00 & NS \\
Chromosome breaks & 0.00 & 0.00 & \\
Dicentric chromosomes & & & \\
\hline
\end{tabular}

NS $=$ Not significant $(p>0.05)$. 
Cytogenetic, immunological, and hematological effects in workers in an ethylene oxide manufacturing plant

Table 5 Duration of employment and chromosome damage. Data show the percentage of aberrant cells \pm 1 ISEM

\begin{tabular}{lccc}
\hline & Group 1 (less than 5 years) & Group 2 (more than 5 years) & Statistical analysis \\
\hline No of metaphases analysed & 1900 & 1700 & \\
Polyploidy & $0.11 \pm 0.07$ & 0.00 & NS \\
Gaps & $0.63 \pm 0.18$ & $1.18 \pm 0.26$ & NS \\
Chromatid breaks & $0.58 \pm 0.17$ & $0.47 \pm 0.17$ & NS \\
Chromosome breaks & $0.16 \pm 0.09$ & $0.29 \pm 0.13$ & NS \\
\hline
\end{tabular}

NS $=$ Not significant $(\mathrm{p}>0.05)$.

significant correlation $(p>0.05)$ between the amount of $\mathrm{Nt}^{-}\left(2^{\prime}\right.$-hydroxyethyl)-L-histidine in haemoglobin and chromosome or chromatid aberrations.

\section{IMMUNOLOGICAL AND HAEMATOLOGICAL}

ANALYSIS

Tables 6 and 7 summarise the haematological profiles and the data for $B$ and $T$ lymphocyte subpopulations in the plant workers and the control group. There was no statistically significant difference between the plant workers and the control group in any of the parameters examined. The lymphocyte count in split samples recorded in the Shell Toxicology Laboratory (Tunstall) (table 7) after a delay of 24 hours was greater than the number recorded with no intervening delay in the site medical department (table 6) in both the plant workers and the controls. This may have been due to a relative increase in lymphocyte count during storage because of a reduction in the numbers of the other cells of the differential count or to a difference in methods between the two laboratories. A comparison of results in workers from groups 1 and 2 also showed no statistically significant difference in any of the parameters recorded (tables 6 and 7). With respect to the influence of other variables, smokers in both the control group and the plant workers showed higher lymphocyte count and B and $T$ cell counts compared with non-smokers, but these differences were not statistically significant. A statistically significant difference was found, however, between the white cell count of smokers and non-smokers. Regression analysis showed that the duration of employment was positively correlated $(p<0.05)$ with the percentage of neutrophils in a differential white cell count and negatively correlated $(p<0.05)$ with the percentage of lymphocytes. This correlation did not hold when age was related with these parameters. Other parameters recorded in tables 6 and 7 showed no correlation with duration of employment or with age. Furthermore, no significant correlation was

Table 6 Haematological profile in plant workers and controls, smokers, and non-smokers. Data show the mean value \pm SEM. (Number of individuals are given in parentheses)

\begin{tabular}{|c|c|c|c|c|c|c|}
\hline & $\begin{array}{l}\text { Plant workers } \\
(n=35)\end{array}$ & $\begin{array}{l}\text { Controls } \\
(n=33)\end{array}$ & Statistical analysis & $\begin{array}{l}\text { Smoking } \\
(n=47)\end{array}$ & $\begin{array}{l}\text { Non-smoking } \\
(\mathrm{n}=21)\end{array}$ & Statistical analysis \\
\hline \multicolumn{2}{|c|}{ 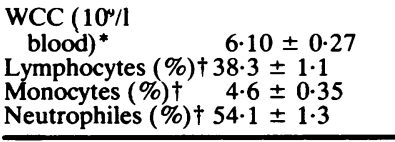 } & $\begin{array}{c}5.95 \pm 0.27 \\
37.5 \pm 1 \cdot 0 \\
5.4 \pm 0.35 \\
53.6 \pm 1.2\end{array}$ & $\begin{array}{l}\text { NS } \\
\text { NS } \\
\text { NS } \\
\text { NS }\end{array}$ & $\begin{array}{c}6.40 \pm 0.15 \\
37.6 \pm 0.9 \\
4.8 \pm 0.3 \\
54.1 \pm 1.3 \\
\end{array}$ & $\begin{array}{c}5 \cdot 05 \pm 0.40 \\
38 \cdot 4 \pm 1 \cdot 3 \\
5 \cdot 5 \pm 0.5 \\
53 \cdot 3 \pm 1 \cdot 5 \\
\end{array}$ & $\begin{array}{l}\mathrm{p}<0.05 \\
\text { NS } \\
\text { NS } \\
\text { NS }\end{array}$ \\
\hline \multicolumn{7}{|c|}{$\begin{array}{l}\text { NS }=\text { Not significant }(p>0.05) \\
\text { *Normal distribution. } \\
\text { †Poisson distribution. }\end{array}$} \\
\hline \multicolumn{7}{|c|}{$\begin{array}{l}\text { Table } 7 \text { Percentage and absolute number of } B \text { and } T \text { cells in whole blood. Data show the mean value } \pm S E M . \text { (Number of } \\
\text { individuals are given in parentheses) }\end{array}$} \\
\hline & $\begin{array}{l}\text { Plant workers } \\
(n=25)\end{array}$ & $\begin{array}{l}\text { Controls } \\
(n=25)\end{array}$ & Statistical analysis & $\begin{array}{l}\text { Smoking } \\
(n=34)\end{array}$ & $\begin{array}{l}\text { Non-smoking } \\
(n=16)\end{array}$ & Statistical analysis \\
\hline $\begin{array}{l}\text { Lymphocytes* } \\
\left(10^{\circ} / 1\right) \\
\text { T Lymphocytes* } \\
\left(10^{\circ} /\right) \\
\text { T Lymphocytes } \\
(\%) \\
\text { B Lymphocytes } \dagger \\
\left(10^{\circ} /\right) \\
\text { B Lymphocytes } \dagger \\
\left(10^{\circ} / 1\right)\end{array}$ & $\begin{array}{l}2 \cdot 24 \pm 0 \cdot 14 \\
72 \cdot 4 \pm 1 \cdot 0 \\
0 \cdot 212 \pm 0 \cdot 020 \\
7 \cdot 1 \pm 0.6\end{array}$ & $\begin{array}{l}2.01 \pm 0.15 \\
70.5 \pm 1 \cdot 2 \\
0.186 \pm 0.023 \\
7 \cdot 0 \pm 0.7\end{array}$ & $\begin{array}{l}\text { NS } \\
\text { NS } \\
\text { NS } \\
\text { NS }\end{array}$ & $\begin{array}{l}71 \cdot 8 \pm 1 \cdot 0 \\
0 \cdot 22 \pm 0 \cdot 021 \\
7 \cdot 3 \pm 0 \cdot 7\end{array}$ & $\begin{array}{l}1.78 \pm 0.16 \\
70.8 \pm 1.4 \\
0.15 \pm 0.018 \\
6.4 \pm 0.7\end{array}$ & NS \\
\hline
\end{tabular}

NS $=$ Not significant.

${ }^{*}$ Normal distribution.

†Log normal distribution. 
Table 8 Lymphocyte activation by maximum stimulation of PHA in vitro. Data show the mean value $\pm S E M$. (Number of individuals are given in parentheses)

\begin{tabular}{lccl}
\hline & $\begin{array}{l}\text { Plant workers } \\
(n=25)\end{array}$ & $\begin{array}{l}\text { Controls } \\
(n=25)\end{array}$ & $\begin{array}{l}\text { Statistical } \\
\text { analysis }\end{array}$ \\
\hline $\begin{array}{l}\text { Maximum } \\
\text { stimulation* } \\
\text { (cpm) }\end{array}$ & $51864 \pm 4133$ & $45362 \pm 3711$ & NS \\
$\begin{array}{c}\text { Background } \dagger \\
\text { (cpm) }\end{array}$ & $598 \pm 104$ & $428 \pm 77$ & NS \\
Stimulation index $\dagger$ & $80 \pm 14$ & $98 \pm 17$ & NS \\
\hline
\end{tabular}

NS $=$ Not significant $(p>0.05)$.

*Normal distribution.

†Log normal distribution.

Stimulation index $=\frac{\mathrm{cpm} \text { Stimulated culture }}{\mathrm{cpm} \text { Unstimulated culture }}$

found $(p>0.05)$ between the amount of $N^{t}-\left(2^{\prime}-\right.$ hydroxyethyl) - L - histidine in haemoglobin and haematological or immunological parameters (tables 6 and 7). Tables 8-10 summarise the effects of variables on $T$ and $B$ cell function. Table 8 shows the data for the in vitro lymphoproliferative response to the mitogen PHA of cultures from plant workers and the control group; table 10 shows the data for humoral immunity. There was no statistically significant difference between plant workers and the control group in respect of any of the parameters recorded in these tables. Furthermore, no statistically significant difference was found between groups 1 and 2 or between these groups and the control group in any of the parameters recorded in tables 8 and 10 . Of the other variables, smoking was associated with a statistically significant decrease on serum IgG and IgM levels (table 10). The response of cultures stimulated by PHA was increased in smokers compared with non-smokers, but the difference was not statistically significant. Furthermore, a statistically significant decrease in the PHA response was observed in the group aged 40-59 compared with groups aged 30-39 and 20-29 (table 9). Regression analysis showed that the PHA response of cultures from plant workers was negatively correlated $(p<0.01)$ with duration of employment. This effect was undoubtedly influenced by age: the relation between age and PHA response was highly significant ( $\mathrm{p}<$ $0 \cdot 01$ ). Other parameters recorded (tables 8 and 10) showed no correlation with either duration of employment or with age.

No significant correlation was found between the amount of $\mathrm{N}^{\mathbf{t}}$-(2'-hydroxyethyl)-L-histidine in haemoglobin and immunological parameters (tables 8 and 10).

\section{Discussion}

Exposure levels to EO in modern manufacturing plants are usually low, generally below $1 \mathrm{ppm}(\mathrm{M}$ Kokestsu, unpublished data). In the current study occupational EO exposure ( 8 h TWA) measured under normal plant operating conditions during 1974-82 was generally below the detection limit of $0.05 \mathrm{ppm}$. Nevertheless, occasional transient concentrations of up to $8 \mathrm{ppm}$ were recorded. It is o also possible that higher exposures than $0.05 \mathrm{ppt}$ may have occurred before 1974 and during plannes closures for maintenance purposes - that is, during the shut down and start up procedures.

No statistically significant increase in the frequency of chromatid or chromosome aberrations was observed in the current study. In the group of $\overline{\vec{a}}$ plant workers the positive correlation $(p<0.05)$ found between the frequency of chromosome breaks and duration of employment was independent of

Table 9 Effect of other variables on lymphocyte activation. Data show the mean value \pm SEM

\begin{tabular}{llllr}
\hline & No of individuals & Maximum stimulation (cpm) & Background (cpm) & Stimulation Index \\
\hline Smoking & 34 & $53594 \pm 3460$ & $487 \pm 72$ & $100 \pm 14$ \\
Non-smoking & 16 & $40152 \pm 3932$ & $547 \pm 128$ & $69 \pm 16$ \\
Age group 20-29 & 22 & $58139 \pm 3947$ & $645 \pm 136$ & $86 \pm 19$ \\
Age group 30-39 & 17 & $47472 \pm 4555$ & $521 \pm 82$ & $297 \pm 71$ \\
Age group 40-59 & 11 & $31325 \pm 3239^{*}$ & 14 & $100 \pm 22$ \\
\hline
\end{tabular}

*Statistical significant difference compared with age groups $20-29$ and $30-39$ years $(\mathrm{p}<0.05)$.

Table 10 Serum immunoglobulin concentrations. Data show the mean value $\pm S E M$. (Number of individuals are given in parentheses)

\begin{tabular}{lllllll}
\hline & $\begin{array}{l}\text { Plant workers } \\
(n=24)\end{array}$ & $\begin{array}{l}\text { Controls } \\
(n=27)\end{array}$ & $\begin{array}{l}\text { Statistical } \\
\text { analysis }\end{array}$ & $\begin{array}{l}\text { Smoking } \\
(n=35)\end{array}$ & $\begin{array}{l}\text { Non-smoking } \\
(n=16)\end{array}$ & $\begin{array}{l}\text { Statistical } \\
\text { analysis }\end{array}$ \\
\hline IgG* (mg\%) & $1565 \pm 58$ & $1500 \pm 41$ & NS & $1467 \pm 39$ & $1679 \pm 57$ & $p<0.05$ \\
IgM† (mg\%) & $152 \pm 11$ & $127 \pm 9$ & NS & $127 \pm 9$ & $164 \pm 8$ & p 0.05 \\
IgA* (mg\%) & $159 \pm 13$ & $160 \pm 10$ & NS & $150 \pm 9$ & $181 \pm 17$ & NS \\
\hline
\end{tabular}

NS = Not significant $(\mathrm{p}>0.05)$.

${ }^{*}$ Log normal distribution.

$\uparrow$ Normal distribution. 
age, suggesting an occupational effect. This statistically significant correlation was based on a single finding of $2 \%$ chromosome breaks in a plant worker with nine years of employment in the EO plant. In six other plant workers and seven control subjects this type of aberration occurred at a rate of $1 \%$. No chromosome breaks were recorded in 29 plant workers and 26 controls. When coupled with the absence of a statistically significant difference in the frequency of chromosome breaks in group 1 compared with group 2 or between these groups and the control group and the consistency with published values for control populations, ${ }^{1617}$ it is unlikely that the statistically significant correlation between duration of employment and frequency of chromosome breaks is of biological significance. These essentially negative findings are in close agreement with the reported absence of chromosome damage in the lowest exposure group in the study conducted by Johnson and Johnson. ${ }^{7}$ It should also be noted that the EO exposures measured in the current study were similar to those determined for the lowest exposure group in the Johnson and Johnson study.

Various aspects of lifestyle may influence the degree of chromosome damage in peripheral blood lymphocytes. For example, several reports indicate increased frequencies of chromatid and chromosome aberrations in smokers compared with non-smokers. ${ }^{1819}$ These increases appeared to be dose related-that is, dependent on the frequency and the total duration of smoking. The results obtained in the current study provide no evidence to support an association between smoking and chromosome aberrations. This failure to detect an effect may have been due to the relatively low average age of the subjects and, possibly, to a low frequency of smoking, particularly among plant workers who are not allowed to smoke on the plant. Analysis of the results of haematological and immunological tests showed no statistically significant differences between plant workers and the control group which suggests that immune function was not altered under the conditions prevailing in the EO manufacturing plant. The finding that in the group of plant workers the percentage of neutrophils in a differential white cell count was increased and the percentage of lymphocytes decreased with duration of employment to EO is probably not of biological significance, because the absolute numbers remained within the normal limits and also because there was no statistically significant difference in the percentages of neutrophils and lymphocytes observed in the plant workers and in the control group.
Smoking had a more profound effect on haematological and immunological parameters as evidenced by a statistically significant increase in white cell count and a decreased level of serum immunoglobulins. These findings are in agreement with several published reports. ${ }^{20}$ Nevertheless, the values for smokers were within the normal range. The fact that these values were significantly different from the control values (non-smokers) suggests that a change in immunological parameters may provide a more sensitive criterion for detecting an effect of smoking than does an increase in chromosome aberrations. Although not directly relevant to the main issue, it should be noted that the previously reported age dependent decrease in the responsiveness of lymphocytes to PHA in vitro ${ }^{21}$ was confirmed in the present study.

In the present study the degree of 2-hydroxyethylation of the $\mathrm{N}^{t}$ atom of histidine residues in the haemoglobin of circulating erythrocytes was measured in the plant workers and in the control group in an attempt to develop precise data regarding recent individual exposures to EO-that is, during the 18 week period immediately before blood sampling.* A surprising feature of the results was the finding of variable but, in most instances, readily measurable quantities of $\mathrm{N}^{\mathrm{t}}$-(2'-hydroxyethyl)-L-histidine in the haemoglobin of the control group, who had not knowingly been exposed to an exogenous source of EO. Indeed, there was no statistically significant difference between the results obtained in the control group and the plant workers, although the latter displayed a tendency towards higher values. Calleman and co-workers calculated that an exposure dose $\dagger$ of $1 \mathrm{ppm} \times \mathrm{h}$ would be equivalent to an in vivo EO dose of $0.106 \mu \mathrm{M} \times \mathrm{h} .{ }^{.1}$ Using this criterion and assuming a repeated and regular pattern of exposure, the average weekly in vivo doses of EO in plant workers $(16.5 \mu \mathrm{M} \times \mathrm{h}$.; table $3)$ and in control personnel $(12.6 \mu \mathrm{M} \times \mathrm{h}$.; table 3) would be equivalent to weekly EO exposure doses of $156 \mathrm{ppm} \times \mathrm{h}$ and $119 \mathrm{ppm} \times \mathrm{h}$ respectively. The observation that there was no statistically significant difference between the in vivo doses in the plant workers and in the controls indicates minimal occupational exposures to EO during the present study. The variable and relatively high background levels of $\mathrm{N}^{\mathrm{t}}-\left(2^{\prime}\right.$-hydroxyethyl)-L-histidine in the control group prevented the calculation of the contribution of the in vivo dose, made by occupational exposure to $\mathrm{EO}$, on an individual basis.

*The life duration of the erythrocyte is 18 weeks in man.

†The exposure dose is expressed in terms of a composite unit, concentration $\times$ time - for instance, $\mathrm{ppm} \times \mathrm{h}$. 
The origin of the variable background of 2-hydroxyethyl groups in the control group is unknown. Several possible sources exist including EO formed during the oxidative metabolism of endogenously synthesised ethylene or an exposure of both groups to ethylene used on site. Smoking and age were not contributing factors of these background alkylations. No statistically significant differences in $\mathrm{N}^{\mathrm{t}}$-(2'-hydroxyethyl)-L-histidine levels were found between smokers and non-smokers, and regression analysis showed that there was no significant correlation $(p>0.05)$ between the amount of adduct and age.

The detection of a variable background of 2-hydroxyethyl groups in the histidine residues of human haemoglobin has clear toxicological and methodological implications. It would be premature, however, to comment further on the possible significance of this finding until the origin of these 2-hydroxyethyl groups has been established and studies have been conducted to determine whether or not a corresponding background of 2-hydroxyethyl groups occurs in DNA. Studies are in progress to investigate these problems.

In summary, no statistically significant difference was found in any of the biological parameters invèstigated in this study between the group of plant workers, employed in EO manufacture for periods of up to 14 years, and the control group. The association between duration of employment in EO manufacture and changes in the frequency of chromosome breaks and in the percentage of neutrophils and lymphocytes in a differential white cell count was not considered to be of biological significance. No statistically significant correlation was found between the amount of $\mathrm{N}^{\mathrm{t}}$-(2'-hydroxyethyl)-L-histidine in the haemoglobin of a particular individual and the frequency of chromosome aberrations and immunological or haematological parameters.

We thank Mr H de Jonge, Shell Nederland Chemie BV, Rotterdam, for carrying out the statistical analysis.

\section{References}

' Fishbein L, Flamm WG, Falk WL. Chemical mutagens. New York/London: Academic Press, 1970.

${ }^{2}$ Embree JW, Hine CH. Mutagenicity of ethylene oxide. Toxicol Appl Pharmacol 1975;33:172-3.

${ }^{3}$ Strekalova EY, Chirkova EM, Holubovich I. The mutagenic effect of ethylene oxide on reproductive and somatic cells in male white rats. Taksikologiiaa Novykh Promyshlennykh Khimicheskikh Veshckestv 1975;14:11-6.
${ }^{4}$ Embree JW, Lyon JP, Hine $\mathrm{CH}$. The mutagenic potential of ethylene oxide using the dominant lethal assay in rats. Toxicol Appl Pharmacol 1977;40:261-7.

${ }^{5}$ Garry VF, Hozier J, Jacobs D, Wade RL, Gray DG. Ethylene oxide: evidence of human chromosomal effects. Environ Mutagen 1979; 1:375-82.

- Thiess AM, Schwegler H, Fleig O, Stocker WG. Mutagenicity study of workers exposed to alkylene oxides (ethylene oxide/ propylene oxide) and derivatives. JOM 1981;23:343-6.

7 Johnson and Johnson Co. Preliminary report of pilot research chromosome study of workers at sites where ethylene oxide gas is utilized as a sterilant. Pesticide and Toxic Chemical News 1982;10:31-2.

${ }^{8}$ Bach JF. The mode of action of immunosuppressive agents. Amsterdam/New York: North Holland Publishing Company, 1975.

9 Osterman-Golkar S, Ehrenberg L, Segerbäck D, Hällstrom I. Evaluation of genetic risks of alkylating agents. II. Haemoglobin as a dose monitor. Mutat Res 1976;34:1-10.

${ }^{10}$ Segerbäck D, Calleman CJ, Ehrenberg L, Löfroth G, Osterman-Golkar S. Evaluation of genetic risk of alkylating agents. IV Quantitative determination of alkylated amino acids in haemoglobin as a measure of the dose after treatment of mice with methyl methanesulfonate. Mutat Res 1978; 49:71-82.

" Calleman CJ, Ehrenberg L, Jansson B, et al. Monitoring and risk assessment by means of alkyl groups in hemoglobin in persons occupationally exposed to ethylene oxide. J Environ Pathol Toxicol 1978;2:427-42.

${ }^{12}$ Ehrenberg L, Osterman-Golkar S. Alkylation of macromolecules for detecting mutagenic agents. Teratogenesis, Carcinogenesis and Mutagenesis 1980;1:105-27.

${ }^{13}$ Ehrenberg L, Hiesche KD, Osterman-Golkar S, Wennberg I. Evaluation of genetic risks of alkylating agents: tissue doses if ? the mouse from air contaminated with ethylene oxide. Mut Res 1974; 24: 83-103.

14 National Institute for Occupational Safety and Health. Ethylent oxide - No $S$ 286. Documentation of the NIOSH validation ${ }^{+}$ tests. Cincinnati: US Department of Health, Education and Welfare, 1977.

${ }^{15}$ Evans HJ, O' Riordan MK. Human peripheral blood lymphocytes for the analysis of chromosome aberrations in mutagen tests. In: Kilbey BJ, Legator M, Nichols W, Ramel C, eds. Handbook of mutagenicity test procedures. Amsterdam: Elsevier, 1977:261-74.

${ }^{16} \mathrm{O}$ 'Riordan ML, Evans HJ. Absence of significant chromosome damage in males occupationally exposed to lead. Nature 1974;247:50-3.

${ }_{17}$ Purchase IFH, Richardson CR, Anderson D, Paddle GM Adams WGF. Chromosomal analyses in vinyl chloride exposed workers. Mutat Res 1978; 57:325-34.

${ }^{18}$ Vijayalaxmi, Evans $\mathrm{HJ}$. In vivo and in vitro effects of cigarette smoke on chromosomal damage and sister-chromatid exchange in human peripheral blood lymphocytes. Mutat Res 1982;92:321-2.

${ }^{19}$ Obe G, Vogt HJ, Madle S, Fahring A, Heller WD. Double blind study on the effect of cigarette smoking on the chromosomes of human peripheral blood lymphocytes in vivo. Mutat Res 1982;92:309-19.

${ }^{20}$ Holt PG, Keast D. Environmentally induced changes in immunological function: acute and chronic effects of inhalation of tobacco smoke and other atmospheric contaminants in man and experimental animals. Bacteriol Rev 1977;41:20516.

${ }^{21}$ Waldorf RL. The immunologic theory of aging: current status. Fed Proc 1974;33:2020. 